Dr A Markus, Thame; Dr D Leggatt, Oxford; Dr M Agass, Berinsfield; Dr D Otterburn, Abingdon; Dr S Street, Kidlington; Dr V Drury, Wantage; Dr R Pinches, Abingdon; Dr N Crossley, Abingdon; and Dr H O'Donnell, Deddington.

\section{Addendum}

Since this report was first prepared a further 175 cases of clinically definite first stroke have been registered. None of the patients had non-stroke lesions detected by CT or found at necropsy. The frequency of non-stroke lesions in patients with a clinically definite first stroke is therefore five out of 498 $\left(1 \cdot 0^{\prime \prime}\right)$.

\section{Appendix}

POSSIBLE INDICATIONS FOR PERFORMING CT SCAN ON PATIENT WITH STROKE

\section{To establish diagnosis:}

Differentiate "stroke" from "non-stroke" in patients with a poor history (dysphasia, confusion, coma) or a progressive deficit

Identify the pathological type of stroke (intracranial haemorrhage or cerebral infarction)

\section{To identify surgically treatable type of stroke:}

Supratentorial haematomas suitable for evacuation

Cerebellar haematomas or infarcts, with or without obstructive hydrocephalus

Arteriovenous malformations or aneurysms

\section{To exclude intracranial haemorrhage:}

Already receiving or before anticoagulant treatment Already receiving or before antiplatelet treatment

Before angiography (for presumed ischaemic minor stroke, etc)
In spontaneous subarachnoid haemorrhage:

Confirm presence of blood

Localise any intracerebral haematoma

Identify site of bleeding

Identify source of bleeding-for example, aneurysm or arteriovenous malformation

Identify cause of deterioration: hydrocephalus, recurrent haemorrhage, cerebral infarction secondary to vasospasm

\section{References}

1 Oxfordshire Community Stroke Project. Incidence of stroke in Oxfordshire: first year's experience of a community stroke register. Br Med f 1983;287: first

2 Hatano S. Experience from a multicentre stroke register; a preliminary report. Allen CMC. Clinical diagnosis of the acute stroke syndrome. Q f Med 1983; 208 (new series LII) :515-23.

4 Weisberg LA, Nice CN. Intracranial tumors simulating the presentation of cerebrovascular syndromes: early detection with cerebral computed tomo-

graphy. Am $\mathcal{F}$ Med 1977;63:517.
Kinkel WR, Jacobs L. Computerized axial tomography in cerebrovascular disease. Neurology 1976;26:924-30.

6 Twomey C. Brain tumours in the elderly. Age Ageing 1978;7:138-44. results of ventricular drainage. Lancet 1982 ;ii:429-31.

infarction: conservative management. Stroke 1983;14:745-51. Müller HR, Wüthrich R, Wiggli $U$, Hünig R, Elke $M$. The contribution of computerized axial tomography to the diagnosis of cerebellar and pontine hematomas. Stroke 1975;6:467-75.

10 McKissock W, Richardson A, Walsh L. Spontaneous cerebellar haemorrhage a study of 34 consecutive cases treated surgically. Brain 1960;83:1-9.

11 Garde A, Böhmer G, Seldén B, Neiman J. 100 cases of spontaneous intracerebral haematoma: diagnosis, treatment and prognosis. Eur Neurol 1983;22:161-72. neous intracerebral

13 Greenberg JO, Skubik DL. Unexpected brain hemorrhages and the value of computed tomography. Computerized Tomography 1977;1:349-57. therapy: computed tomography or lumbar puncture. Neurology 1981;31: 736-40.

15 von Arbin M, Britton M, de Faire U, Helmers C, Miah K, Murray V. Accuracy of bedside diagnosis in stroke. Stroke 1981;12:288-93.

6 Bergstrom M, Ericson K, Levander B, Svendson P, Larsson S. Variation with time of the attenuation values of intracranial hematomas. $f$ Comput Assist Tomogr 1977;1:57-63.

17 UK-TIA Study Group. Variation in the use of angiography and carotid endarterectomy by neurologists in the UK-TIA aspirin trial. Br Med $\mathcal{F} 1983$;

(Accepted 19 October 1984)

\title{
Smoking and coronary artery disease assessed by routine coronary arteriography
}

\author{
DAVID R RAMSDALE， ERIC B FARAGHER，COLIN L BRAY， DAVID H BENNETT, \\ CHRISTOPHER WARD, DAVID C BETON
}

\begin{abstract}
The association between extent and duration of smoking habit and severity of coronary atheroma was examined in 387 patients undergoing routine coronary ateriography before valve replacement surgery. Total number of cigarettes smoked in life correlated significantly with
\end{abstract}

Regional Cardiac Unit, Wythenshawe Hospital, Manchester M23 9LT

DAVID R RAMSDALE, MD, MRCP, senior registrar in cardiology

ERIC B FARAGHER, MSC, FSS, senior medical statistician

COLIN L BRAY, BSC, FRCP, consultant cardiologist

DAVID H BENNETT, MD, MRCP, consultant cardiologist

CHRISTOPHER WARD, MD, MRCP, consultant cardiologist

DAVID C BETON, BSC, DMRD, consultant radiologist

Correspondence to: $\mathrm{Dr}$ D R Ramsdale, Regional Cardiothoracic Unit, Broadgreen Hospital, Liverpool L14 3LB. severity of coronary artery disease $(p<0.001)$ and number of coronary arteries with stenoses of $50 \%$ or more $(p<$ 0.001). Severity of coronary artery disease in current smokers was similar to that in former smokers. Multiple regression analysis showed diastolic blood pressure, cigarette consumption, age, ratio of total cholesterol to high density lipoprotein cholesterol, and history of angina to be the important predictors of severity of coronary artery disease.

An estimate of the number of cigarettes smoked in life can be useful in identifying patients with coronary artery disease if used in conjunction with data on other important risk factors.

\section{Introduction}

Since White first described an association between smoking and myocardial infarction ${ }^{1}$ numerous studies have shown the same association. ${ }^{2-8}$ Most prospective epidemiological studies with 
sufficient data have shown that the incidence of developing coronary heart disease is directly related to the number of cigarettes smoked. ${ }^{9-12}$ Myocardial infarction ${ }^{513-15}$ and sudden death $^{16}{ }^{17}$ occur two and four times, respectively, more often in heavy smokers than in non-smokers. Overall the risk for smokers dying from coronary heart disease is twice that for nonsmokers, ${ }^{17-19}$ but among those smoking more than 20 cigarettes a day ${ }^{17} 20$ and those starting to smoke before the age of $20^{21}$ the risks are between three and five times those for non-smokers.

Although necropsy studies have reported that coronary atheroma is increased in cigarette smokers, ${ }^{22}{ }^{23}$ only one small study has correlated cigarette consumption with the severity of coronary artery disease found at arteriography. ${ }^{24}$ In a large prospective study we examined the association between the quantity of cigarettes smoked and duration of the habit and the severity of coronary artheroma in patients undergoing routine coronary arteriography before valve replacement surgery, as such patients are probably more representative of the general population than those with clinical evidence of ischaemic heart disease. The value of a detailed history of cigarette smoking for predicting the presence and severity of coronary artery disease was also assessed as was the interrelation between smoking and the other coronary risk factors.

\section{Patients and methods}

In 1980,387 patients underwent routine coronary arteriography before valve surgery at this hospital. The arteriograms were scored independently by a radiologist using coronary artery maps to indicate the site and severity of the lesions. ${ }^{25} \mathrm{~A}$ severe stenosis of the left main stem or left anterior descending coronary artery carried a high score, whereas a distal irregularity in a non-dominant right coronary artery carried a low score. The total score reflected the overall severity of the coronary artery disease, and the number of vessels affected indicated the extent of the disease.

All patients gave details of their past and present smoking habits including age at starting and stopping and the average number of cigarettes smoked each week. These data allowed us to estimate the number of cigarettes that each patient had smoked in his or her lifetime. In addition to the clinical history and physical examination, blood samples for estimating fasting serum lipid and blood glucose concentrations were collected in $90 \%$ of patients. The specimens were analysed using standard techniques. ${ }^{26} 27$

\section{STATISTICAL ANALYSIS}

Categorical data were analysed using $\chi^{2}$ tests for association. Age, blood pressure, and serum lipid concentration were examined using a one way analysis of variance and the Tukey multiple comparison tests. The numbers of cigarettes smoked in patients' lifetimes and coronary scores were not normally distributed and were therefore analysed using either non-parametric tests (Kruskal-Wallis test and Spearman correlation coefficient) or a logarithmic transformation (multiple regression analysis).

\section{Results}

We studied 180 men and 207 women with mean (SD) ages 54.0 $(10.7)$ and $54 \cdot 8(8 \cdot 8)$ years respectively. One hundred and forty nine had aortic, 122 mitral, and 115 both aortic and mitral valve disease. One patient had pulmonary stenosis. Two hundred and twenty nine patients had been or were currently cigarette smokers, and 151 were non-smokers. There were three cigar and four pipe smokers.

Age, sex, cigarette smoking, and coronary artery disease-Age was significantly correlated with overall severity of coronary artery disease (coronary score) $(r=0.260 ; p<0.001)$, although there was no correlation between age and total number of cigarettes smoked $(r=$ $0.046 ; p=0.364)$. The median (range) coronary scores for men and women were $4.0(0-45)$ and $0.3(0-50)(p<0.001)$. Men smoked significantly more cigarettes than women $(\mathrm{p}<0.001)$.

Angina, cigarette smoking, and coronary artery disease-One hundred and forty two patients $\left(36 \cdot 7^{\circ}\right.$ o had angina. Sixty five $\left(45 \cdot 7^{\circ}\right)$ of these patients had appreciable coronary artery disease in contrast with 47
$(19.2 \%)$ of 245 patients without angina $(p<0.001)$. Of those with angina, $93(65.5 \%)$ were either current or ex-smokers in contrast with $135(55.1 \%)$ of those without angina $(p=0.055)$. The median (range) numbers of cigarettes smoked in life by those with and without angina were $1.10 \times 10^{5}\left(0-8.08 \times 10^{5}\right)$ and $0.47 \times 10^{5}\left(0-8.74 \times 10^{5}\right)$ respectively $(\mathrm{p}=0.01)$. Of the 174 patients with abnormal coronary arteriograms, $129(74 \cdot 1 \%)$ were cigarette smokers compared with $100(48 \cdot 5 \%)$ of 206 patients with normal coronary arteries $(\mathrm{p}<0 \cdot 001)$. One hundred and six $\left(70 \cdot 2^{\circ}\right)$ of the 151 non-smokers had normal coronary arteries in contrast with only $100(43.7 \%)$ of the smokers $(p<0.001)$.

Of the 112 patients with appreciable coronary artery disease (one or more stenoses of $50 \%$ or more), $90(80.4 \%$ ) were current or former cigarette smokers in comparison with $137(50.5 \%)$ of 275 patients without appreciable disease $(\mathrm{p}<0.001)$. The median (range) numbers of cigarettes smoked in life were $2.05 \times 10^{5}\left(0-8.08 \times 10^{5}\right)$ for patients with appreciable coronary artery disease and $0.05 \times 10^{5}\left(0-8.74 \times 10^{5}\right)$ for those without $(\mathrm{p}<0.001)$.

Cigarette smoking and the severity of coronary artery disease-The figure shows the range of coronary scores in patients with various cigarette smoking habits. The median (range) coronary score for smokers (current and former) was $4.6(0-45)$ compared with 0.2 $(0-50)$ for non-smokers $(p<0 \cdot 001)$. There was a significant correlation between coronary score and the total number of cigarettes smoked in life $(r=0.373 ; p<0.001)$. The number of coronary arteries affected by one or more appreciable stenoses was significantly greater in smokers than non-smokers $\left(\chi^{2}=32.70 ; p<0.001\right)$ (table I). Moreover, there was a significant correlation between the total number of cigarettes smoked and the number of coronary arteries with appreciable disease $(r=0.350 ; p<0.001)$. The severity of coronary artery disease in current smokers was similar to that in former smokers irrespective of whether they had given up smoking five or 10 years previously (table II). The median (range) numbers of cigarettes smoked by current $\left(1.89 \times 10^{5}\left(0.02-7.43 \times 10^{5}\right)\right)$ and former $(1.45 \times$ $\left.10^{5}\left(0 \cdot 18-8.74 \times 10^{5}\right)\right)$ smokers were not, however, significantly different $(p=0 \cdot 242)$. Based on the number of packs smoked a day (one pack $=20$ cigarettes), the severity of coronary artery disease was greater in those smoking two or more packs a day than in those smoking less than that $(\mathrm{p}<0.001)$ (table III).

TABLE I-Relation between cigarette smoking and number of coronary arteries with appreciable stenoses. (Three pipe and four cigar smokers excluded)

\begin{tabular}{cccc}
\hline & \multicolumn{3}{c}{ No $\left({ }_{0}, 0\right)$ of: } \\
\cline { 2 - 4 } $\begin{array}{c}\text { No of coronary arteries } \\
\text { affected }\end{array}$ & $\begin{array}{c}\text { Non-smokers } \\
(\mathrm{n}=151)\end{array}$ & $\begin{array}{c}\text { Former smokers } \\
(\mathrm{n}=66)\end{array}$ & $\begin{array}{c}\text { Current smokers } \\
(\mathrm{n}=163)\end{array}$ \\
\hline 0 & $131(86 \cdot 7)$ & $42(63 \cdot 6)$ & $97(59 \cdot 5)$ \\
1 & $11(7 \cdot 3)$ & $10(15 \cdot 2)$ & $22(13 \cdot 5)$ \\
2 & $5(3 \cdot 3)$ & $7(10 \cdot 6)$ & $24(14 \cdot 7)$ \\
3 & $3(2 \cdot 0)$ & $2(3 \cdot 0)$ & $10(6 \cdot 1)$ \\
4 & $1(0 \cdot 6)$ & $5(7 \cdot 6)$ & $10(6 \cdot 1)$ \\
\hline
\end{tabular}

TABLE II-Severity of coronary artery disease in current and former cigarette smokers. ${ }^{*}$ (Three pipe smokers and four cigar smokers excluded)

\begin{tabular}{lrc}
\hline & $\mathrm{n}$ & $\begin{array}{c}\text { Median (range) } \\
\text { coronary score }\end{array}$ \\
\hline Non-smokers & 151 & $0 \cdot 2(0-50)$ \\
Current smokers & 163 & $2 \cdot 8(0-44)$ \\
Ex-smokers for $<5$ years & 29 & $5 \cdot 0(0-45)$ \\
Ex-smokers for 5-9.9 years & 17 & $5 \cdot 0(0-44)$ \\
Ex-smokers for $\geqslant 10$ years & 20 & $7 \cdot 5(0-30)$ \\
\hline
\end{tabular}

*Ex-smokers $v$ current smokers : $\mathrm{p}=0.659$

TABLE III-Relation between smoking habit and severity of coronary artery disease according to current cigarette consumption*

\begin{tabular}{lrc}
\hline Smoking habit & $\mathrm{n}$ & $\begin{array}{c}\text { Median (range) } \\
\text { coronary score }\end{array}$ \\
\hline Non-smokers & 151 & $0 \cdot 2(0-50)$ \\
Current smokers by No of packs $\dagger$ smoked a day: & 67 & $1 \cdot 8(0-44)$ \\
$\sum_{1-1} 1.9$ & 78 & $2 \cdot 5(0-43)$ \\
$\geqslant 2$ & 18 & $8 \cdot 5(0-39)$ \\
\hline
\end{tabular}

${ }^{*} \mathrm{p}<0.001$.

tOne pack $=20$ cigarettes. 
Cigarette smoking and other coronary risk factors-Table IV provides clinical and risk factor data for smokers and non-smokers and table $V$ shows the relation between cigarette consumption and the presence of such risk factors. Significant direct correlations exist between cigarette consumption and systolic and diastolic blood pressure, serum tri- glyceride concentrations, and the ratio of total cholesterol to high density lipoprotein cholesterol. A significant inverse correlation exists with the serum high density lipoprotein cholesterol concentration.

The box shows the clinical and risk factor variables studied by

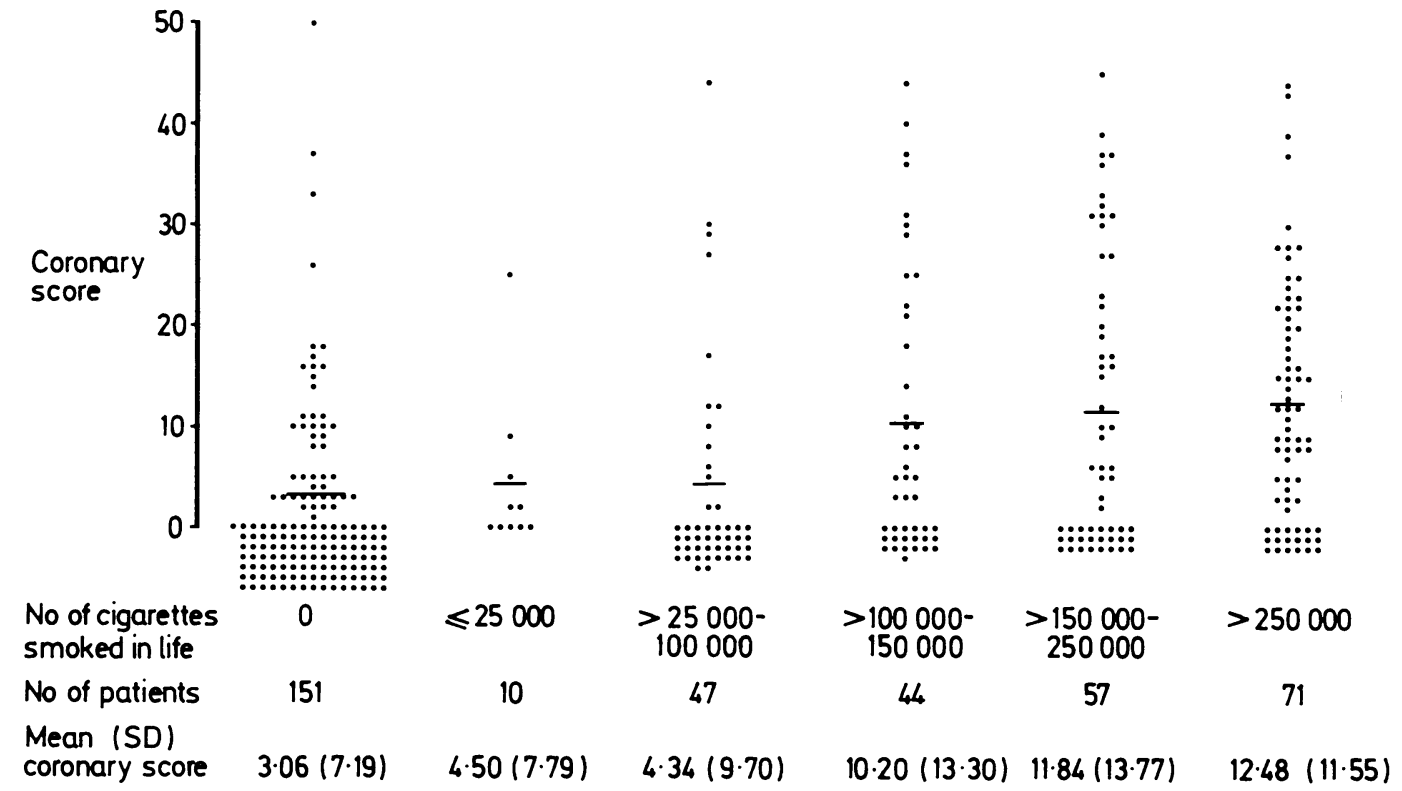

Relation between severity of coronary artery disease (coronary score) and number of cigarettes smoked in life. (Three pipe and four cigar smokers excluded.)

TABLE IV-Association between smoking habit and other coronary risk factors. (Three pipe and four cigar smokers excluded)

\begin{tabular}{|c|c|c|c|}
\hline & $\begin{array}{l}\text { Non-smokers } \\
\quad(n=151)\end{array}$ & $\begin{array}{l}\text { Former smokers } \\
\qquad(n=66)\end{array}$ & $\begin{array}{l}\text { Current smokers } \\
\quad(n=163)\end{array}$ \\
\hline $\begin{array}{l}\text { No of men } \\
\text { Mean (SD) (years) } \\
\text { Mean (SD) systolic blood pressure (mm Hg) } \\
\text { Mean (SD) diastolic blood pressure }(\mathrm{mm} \mathrm{Hg}) \\
\text { No with family history of ischaemic heart disease } \\
\text { No overweight } \$ \\
\text { No with diabetes mellitus } \\
\text { Mean (SD) blood glucose (mmol/l) } \\
\text { Mean (SD) total cholesterol }(\mathrm{mmol} / 1) \\
\text { Mean (SD) high density lipoprotein cholesterol (mmol/l) } \\
\text { Mean (SD) cholesterol ratio } \\
\text { Mean (SD) serum triglycerides (mmol/l) }\end{array}$ & $\begin{array}{l}38 \\
54 \cdot 9(10 \cdot 0) \\
142 \cdot 0(20 \cdot 0) \\
82 \cdot 4(9 \cdot 8) \\
32 \\
13 \\
8 \\
5 \cdot 19(1 \cdot 71) \mathrm{n}=140 \\
5.96(1.33) \mathrm{n}=134 \\
1.20(0.39) \mathrm{n}=133 \\
5 \cdot 40(1.91) \mathrm{n}=133 \\
1.59(0.73) \mathrm{n}=133\end{array}$ & $\begin{array}{l}50 * * * \\
56 \cdot 7(9 \cdot 5) \\
148 \cdot 9(20 \cdot 0) * \\
87 \cdot 2(10 \cdot 6)^{* *} \\
22 \\
6 \\
5 \\
5 \cdot 01(1 \cdot 12) \mathrm{n}=63 \\
6 \cdot 16(1 \cdot 39) \mathrm{n}=61 \\
1.09(0.41) \mathrm{n}=61 \\
6 \cdot 06(1 \cdot 72) * \mathrm{n}=61 \\
1 \cdot 88(0 \cdot 75) \mathrm{n}=61\end{array}$ & $\begin{array}{l}84+ \\
53 \cdot 1(9 \cdot 2) \\
147 \cdot 9(22 \cdot 6) \dagger \\
84 \cdot 2(11 \cdot 7) \\
49 \\
8 \\
2 \\
4.90(1 \cdot 71) \mathrm{n}=157 \\
5 \cdot 90(1 \cdot 41) \mathrm{n}=149 \\
1 \cdot 12(0 \cdot 47) \mathrm{n}=148 \\
5 \cdot 90(2 \cdot 18) \dagger \mathrm{n}=148 \\
1 \cdot 74(0 \cdot 70) \mathrm{n}=149\end{array}$ \\
\hline
\end{tabular}

Significance of difference between non-smokers and former smokers: $* \mathrm{p} \leqslant 0.05 ; * * \mathrm{p} \leqslant 0.01 ; * * * \mathrm{p} \leqslant 0.001$

Significance of difference between non-smokers and current smokers: $+p<0.05,+p<0.001$

All other differences non-significant.

\$Fifteen per cent or more above mean weight for height.

Total cholesterol: high density lipoprotein cholesterol. Conversion: SI to traditional units-Glucose: $1 \mathrm{mmol} / 1 \approx 18 \mathrm{mg} / 100 \mathrm{ml}$. Cholesterol: $1 \mathrm{mmol} / 1 \approx 38.6 \mathrm{mg} / 100 \mathrm{ml}$. Triglyceride: $1 \mathrm{mmol} / 1$
$\approx 88.5 \mathrm{mg} / 100 \mathrm{ml}$.

TABLE $\mathrm{v}$-Relation between total number of cigarettes smoked in life and other coronary risk factors

\begin{tabular}{|c|c|c|c|}
\hline Coronary risk factor & $\begin{array}{l}\text { Median (range) No of } \\
\text { cigarettes smoked }\end{array}$ & $\mathbf{r}$ & p values \\
\hline \multicolumn{4}{|l|}{ Sex: } \\
\hline $\begin{array}{l}\text { Men } \\
\text { Women }\end{array}$ & $\left.1.46 \times 10^{5}\left(0-8.74 \times 10^{5}\right)\right\}$ & & 0.001 \\
\hline $\begin{array}{l}\text { Women } \\
\text { Age }\end{array}$ & & & \\
\hline Systolic blood pressure & & $0 \cdot 164$ & 0.002 \\
\hline Diastolic blood pressure & & $0 \cdot 175$ & 0.001 \\
\hline $\begin{array}{l}\text { Family history of ischaemic } \\
\text { heart disease: }\end{array}$ & & & \\
\hline Yes & $\left.1.09 \times 10^{5}\left(0-8.08 \times 10^{5}\right)\right\}$ & & 0.028 \\
\hline \multicolumn{4}{|c|}{$0.40 \times 10(0-8.14 \times 10))$} \\
\hline Yes & $\left.0.06 \times 10^{5}\left(0-8.08 \times 10^{5}\right)\right\}$ & & 0.335 \\
\hline $\begin{array}{l}\text { No } \\
\text { Diabetes mellitus: }\end{array}$ & $\left.0.73 \times 10^{5}\left(0-8.74 \times 10^{5}\right)\right\}$ & & \\
\hline $\begin{array}{l}\text { Yes } \\
\text { No }\end{array}$ & $\left.\begin{array}{l}0.06 \times 10^{5}\left(0-5.24 \times 10^{5}\right) \\
0.73 \times 10^{5}\left(0-8.74 \times 10^{5}\right)\end{array}\right\}$ & & $0 \cdot 239$ \\
\hline $\begin{array}{l}\text { Blood glucose }(n=365) \\
\text { Total cholesterol }(n=350)\end{array}$ & & $\begin{array}{r}-0.014 \\
0.023\end{array}$ & $\begin{array}{l}0.788 \\
0.667\end{array}$ \\
\hline $\begin{array}{l}\text { High density lipoprotein } \\
\text { cholesterol }(n=348)\end{array}$ & & $-0 \cdot 167$ & 0.002 \\
\hline $\begin{array}{l}\text { Total : high density lipoprotein } \\
\text { cholesterol ratio }(n=346)\end{array}$ & & $0 \cdot 162$ & 0.003 \\
\hline Serum triglycerides $(n=349)$ & & 0.153 & 0.005 \\
\hline
\end{tabular}

*Fifteen per cent or more above mean weight for height.
Age $c$

Sex

Percentage above weight for height

History of angina $e$

Family history of ischaemic heart disease

History of diabetes mellitus

History of hypertension

More than two blood pressure recordings $>150 / 90 \mathrm{~mm} \mathrm{Hg}$

Systolic blood pressure at presentation

Diastolic blood pressure at presentation $a$

Total number of cigarettes smoked $b$

Total serum cholesterol concentration

High density lipoprotein cholesterol concentration

Total: high density lipoprotein cholesterol ratio $d$

Fasting blood glucose concentration

Serum triglyceride concentration

$a-\epsilon$ Order of entry to multiple regression equation for predicting coronary score (all $\mathrm{p}<0.001)$. 
multiple regression analysis, which showed diastolic blood pressure, cigarette consumption, age, ratio of total to high density lipoprotein cholesterol, and history of angina to be the important predictors of coronary score. No other variables were significant at $0 \cdot 1 \%$ level.

\section{Discussion}

Our findings support the current epidemiological evidence in favour of an association between cigarette smoking and coronary artery disease. ${ }^{910}$ Such an association has not been reported previously in patients undergoing routine coronary arteriography, although a similar relation has been found in 113 patients with angina undergoing investigation before coronary bypass surgery. ${ }^{24}$ As there is no evidence to suggest that patients with valvular heart disease have more coronary atheroma than members of the general population we suggest that this relation between cigarette smoking and coronary artery disease may exist in the general population as well as in patients with clinical evidence of ischaemic heart disease.

An estimate of the total number of cigarettes smoked in life correlated with the overall severity of coronary artery disease as well as with the number of coronary arteries with appreciable stenoses. When assessing the importance of cigarette smoking as a risk factor for coronary artery disease we found that such an estimate of previous as well as current smoking habits (quantity and duration of risk exposure) was more valuable than the number of packs currently being smoked. Pack years (packs or fractions of packs per day times years) may be similarly useful. Former cigarette smokers-that is, people who, having smoked for at least 10 years, had stopped for at least one year-had no less appreciable coronary artery disease than current smokers irrespective of whether they had stopped smoking five or 10 years before. The numbers of cigarettes smoked for current and former smokers did not, however, differ significantly. To our knowledge no current evidence is available to suggest that coronary atheroma per se regresses on stopping smoking, although the major epidemiological prospective studies have shown that subsequent death rates are lower in people who stop smoking than in those who continue smoking. ${ }^{4028}$ The reduction in the incidence of myocardial infarction and death after stopping smoking is likely to be due to some other beneficial effects of stopping such as lower catecholamine concentrations, lower serum carboxyhaemoglobin concentrations, reduced blood viscosity, reduced endothelial hypoxia, reduced platelet adhesiveness, or reduced tendency to ventricular arrhythmias. ${ }^{29}$

Necropsy studies support the epidemiological and current arteriographic findings in showing an increased prevalence of coronary atherosclerosis in cigarette smokers. Auerbach et al initially reported advanced coronary atheroma three times more often in men smoking two packs (40 cigarettes) a day than in those not smoking regularly ${ }^{22}$ and subsequently reported that microscopic fibrous intimal thickening of coronary arteries was related to cigarette consumption. This relation was particularly pronounced in the myocardial arterioles. Here the strongest association with cigarette smoking was found with hyaline thickening of the myocardial arterioles, which was observed in $98.6 \%$ of those smoking two or more packs a day and never in non-regular smokers. Although in our study we could not assess this last correlation, these findings are important when relating the histopathological and clinical effects of cigarette smoking on the myocardium.

The complex interrelation between cigarette smoking and other cardiovascular risk factors makes assessing the importance of smoking habit as an independent risk factor for coronary disease difficult. We have shown the limited value of a history of cigarette smoking as a sole indicator of the presence and severity of coronary artery disease and presume that this is due to the multifactorial aetiology of the disease process. Nevertheless, here, and in a previous study, ${ }^{30}$ we have established using multiple regression analysis that an estimate of the number of $\underline{\square}$ cigarettes smoked in life can be useful for identifying patients with coronary artery disease when taken in conjunction with data $\stackrel{\unrhd}{\varrho}$ on arterial blood pressure, age, family history of ischaemic heart $c$ disease, severity of angina, and the ratio of total to high density lipoprotein cholesterol.

We thank Mrs C A McLaughlin for typing the manuscript.

\section{References}

1 White PD. Coronary disease and coronary thrombosis in youth; analysis of 4 cases under the age of 30 years, 21 cases under age of 40 years and 138 cases under age of 50 years. $\mathcal{F}$ Med Soc NF 1935;32:596-605.

2 English JP, Willius FA, Berkson J. Tobacco and coronary disease. FAMA 1940; 115:1327-9.

Hammond EC, Horn D. Smoking and death rates-report on forty-four month oll R, Hill AB. Mortalityen. 1. Total mortality. F AMA 1958,166:1159-72. British doctors. Br Med $71964 ;$ ii $1399-440,1460-7$. 5 Doyle JT, Dawber TR, Kannel WB, Kinch SH, Kahn HA. The relationship of cigarette smoking to coronary heart disease; the second report of the combined experience of the Albany, NY and Framingham, Massachusetts studies. fAMA 1964;190:886-90.

6 Stamler J, Berkson DM, Levinson M. Coronary artery disease. Status of preventive efforts. Arch Environ Health 1966;13:322-35.

7 Kannel WB, Castelli WP, McNamara PM. Cigarette smoking and risk of coronary heart disease. Epidemiologic clues to pathogenesis. The Framingham study.

8 Tibblin G. Risk factors in coronary heart disease. Adv Cardiol 1970:4.123-30. Kannel WB, McGee D, Gordon T. A general cardiovascular risk profile. The Framingham study. Am $\mathcal{F}$ Cardiol 1976;38:46-51. 10 Rosenman RH, Brand RJ, Sholtz RI, Friedman M. Multivariate prediction of coronary heart disease during 8.5 year follow-up in the Western Collaborative Group Study. Am $\mathcal{I}$ Cardiol 1976;37:903-10.

11 Bain C, Hennekens CH, Rosner B, Speizer FE, Jesse MJ. Cigarette consumption and deaths from coronary artery disease. Lancet $1978 ; \mathrm{i}: 1087-8$.

12 Friedman GD, Dales LG, Ury HK. Mortality in middle-aged smokers and nonsmokers. N Engl f Med 1979;300:213-7.

pre table analysis in a prospective

14 Intersociety Commission for Heart Disease Resources. Primary prevention of the atherosclerotic diseases. Circulation 1970;42:A55-95.

15 Stamler J, Epstein FH. Coronary heart disease. Risk factors as guides to preven tive action. Prev Med 1972;1:27-48.

16 Stamler J. Cigarette smoking and atherosclerotic coronary heart disease. Bull NY Acad Med 1968;44:1476-94.

17 Ball K, Turner R. Smoking and the heart. The basis for action. Lancet 1974; ii :

18 Doyle JT, Dawber TR, Kannel WB, Heslin AS, Kahn HA. Cigarette smoking and coronary heart disease Combined experience of the Albany and Framingham studies. N Engl 7 Med 1962;26:796-801.

19 Reid DD, Hamilton PJ, McCartney P, Rose G, Jarrett RJ, Keen H. Smoking and other risk factors for coronary heart disease in British civil servants. Lancet 1976;ii:979-84.

$20 \mathrm{Kahn} \mathrm{HA}$. The Dorn study of smoking and mortality among US veterans report on eight and one half years of observation. Natl Cancer Inst Monog

21 Hirayama T. Smoking in relation to the death rates of 265,118 men and women in Japan. A report of 5 years' follow up. Presented at the American Cance of the coronary arteries. NEngl f Med 1965;273:775-9.

23 Auerbach O, Carter HW, Garfinkel L, Hammond EC. Cigarette smoking and coronary artery disease. A macroscopic and microscopic study. Chest 1976 70:697-705.

24 Herbert WH. Cigarette smoking and arteriographically demonstrable coronar artery disease. Chest $1975 ; 67: 49-52$

25 Ramsdale DR. Observations on coronary artery disease in patients with valvula heart disease. Manchester: University of Manchester, 1981. MD thesis.

26 Technicon Instruments Corporation. Cholesterol and triglycerides (enzymatic). Methods for SMA II, computer-controlled multichannel binchemical analyzer. Tarrytown, New York: Technicon Instruments Corporation, 1977:1-8.

27 Lopes-Virella MF, Stone P, Ellis S, Colwell JA. Cholesterol determination in high density lip

28 Gordon T, Kannel WB, McGee D, Dawber TR. Death and coronary attacks in men after giving up cigarette smoking. A report from the Framingham study. Lancet 1974;ii:1345-8.

29 Levy RI, Feinleib M. Risk factors for coronary artery disease and their management. In: Braunwald, ed. Heart disease: a textbook of cardiovasiular medicine. Pamsdale DR, Faragher EB, Bennett DH, Bray CL, Ward C, Beton DC. Preoperative prediction of significant coronary artery disease in patients with operative prediction of significant coronary arter
valvular heart disease. Br Med $\mathcal{f} 1982 ; 284: 223-6$.

(Accepted 19 October 1984)

\section{Correction}

Perforation of intestinal duplication by enteroliths after trauma

We regret that an error occurred in this article by $\mathrm{Mr} P \mathrm{~V}$ Marks and Mr A E Stuart (22-29 December, p 1744). Mr A E Stuart's name was wrongly spelt as A E Stunt. 